\title{
Podstawy społecznej koncepcji Rosyjskiego Kościoła Prawosławnego: problemy bioetyki i ekologii
}

\author{
ks. Artur Aleksiejuk \\ Chrześcijańska Akademia Teologiczna w Warszawie, \\ Wydział Nauk Społecznych, Katedra Dydaktyki i Pedagogiki Porównawczej, \\ Polska \\ ORCID: 0000-0002-5827-6048 \\ a.aleksiejuk@chat.edu.pl
}

rev. A. Aleksiejuk, The Basis of the Social Concept of the Russian Orthodox Church: Problems of Bioethics and Ecology, Elpis, 22 2020: $95-105$

\begin{abstract}
The foundations of the social concept are one of the most important normative acts issued by the Russian Orthodox Church. The unanimous adoption of this document by the Holy Council of Bishops of the Russian Church, which took place on August 13-16, 2000 in Moscow, was not only a local event, but a significant fact on the scale of the entire Orthodox Church worldwide. For the first time in history, one of the autocephalous Orthodox Churches decided to formulate an official position on current social, economic, economic and cultural issues, as well as define the Church-state relationship in the conditions of historical reality in which it found itself at the threshold of the third millennium. The promulgation of the Foundations of the Social Concept has become a powerful impulse for the renewal of spiritual life, greater involvement of the Orthodox clergy in social life, the development of institutional and non-institutional forms of mission and evangelization, and the multidimensional dialogue of Orthodoxy with the world of science, politics and economy. The aim of this publication is to familiarize the Polish reader with the content of chapters twelve and thirteen of the document, which relate to bioethical and ecological issues. It is worth noting that this is their first translation into Polish. The translator hopes that they will contribute to a better understanding of the Orthodox Church's position on issues that are currently among the most discussed social topics.
\end{abstract}

\begin{abstract}
Streszczenie: Podstawy koncepcji społecznej to jeden z najważniejszych aktów normatywnych wydanych przez Rosyjski Kościół Prawosławny. Jednogłośne przyjęcie tego dokumentu przez Święty Sobór Biskupów rosyjskiej Cerkwi, który odbył się w dniach 1316 sierpnia 2000 roku w Moskwie, było nie tylko wydarzeniem o zasiegu lokalnym, lecz znaczacym faktem w skali całego światowego prawosławia. Po raz pierwszy w dziejach jeden z autokefalicznych Kościołów prawosławnych zdecydował się na sformułowanie oficjalnego stanowiska wobec aktualnych kwestii społecznych, gospodarczo-ekonomicznych i kulturowych, a także zdefiniowanie relacji Kościół-państwo w warunkach rzeczywistości historycznej, w której się znalazł na progu trzeciego tysiąclecia. Promulgacja Podstaw koncepcji społecznej stało się potężnym impulsem do odnowy życia duchowego, większego zaangażowania prawosławnego duchowieństwa w życie społeczne, rozwoju instytucjonalnych i pozainstytucjonalnych form misji i ewangelizacji, wielopłaszczyznowego dialogu prawosławia ze światem nauki, polityki i gospodarki. Celem niniejszej publikacji jest zapoznanie polskiego czytelnika z treścią rozdziału dwunastego i trzynastego dokumentu, które odnoszą się do problematyki bioetycznej i ekologicznej. Warto podkreślić, że jest to ich pierwsze thumaczenie na język polski. Tłumacz wyraża nadzieję, że przyczynią się one do lepszego poznania stanowiska Kościoła prawosławnego wobec kwestii, które obecnie należą do najbardziej dyskutowanych tematów społecznych.
\end{abstract}

Keywords: Social Concept of the Russian Orthodox Church, orthodoxy and bioethics, orthodoxy and ecology, social doctrine of the Orthodox Church, Church and contemporary problems

Słowa kluczowe: Koncepcja społeczna Rosyjskiego Kościoła Prawosławnego, prawosławie i bioetyka, prawosławie i ekologia, nauka społeczna Kościoła prawosławnego, Kościół i problemy współczesności

\section{Wprowadzenie}

W sierpniu 2020 roku przypada dwudziesta rocznica przyjęcia przez Święty Sobór Biskupów Rosyjskiego Kościoła Prawosławnego dokumentu zatytułowanego Podstawy koncepcji spotecznej Rosyjskiego Kościoła Prawosławnego (Osnovy social'noj koncepcii..., 2000). Jednogłośnej promulgacji tego aktu dokonano $\mathrm{w}$ dniu 15 sierpnia 2000 roku w soborze Chrystusa Zbawiciela w Moskwie w obecności 146 prawosławnych biskupów z Rosji i kanonicznych struktur Rosyjskiego Kościoła Prawosławnego poza jej granicami.
Praca nad dokumentem, w Preambule którego stwierdzono, iż ,stanowi on wyraz oficjalnego stanowiska Patriarchatu Moskiewskiego w przestrzeni stosunków z Państwem i społeczeństwem świeckim", a także ustanawia „szereg zasad, którymi w danym obszarze powinien kierować się episkopat, duchowieństwo i wierni" (Osnovy social'noj koncepcii..., 2000), trwała trzy i pół roku. Dokument składa się z Preambuly i szesnastu rozdziałów, których układ przedstawia się w następujący sposób:

Rozdział I - Podstawowe założenia teologiczne

Rozdział II - Kościół i naród

Rozdział III - Kościół i państwo 
Rozdział IV - Etyka chrześcijańska i prawo świeckie

Rozdział V - Kościół i polityka

Rozdział VI - Praca i jej owoce

Rozdział VII - Własność

Rozdział VIII - Wojna i pokój

Rozdział IX - Przestępczość, kara, poprawa

Rozdział X - Problemy moralności indywidualnej, rodzinnej i społecznej

Rozdział XI - Zdrowie osoby i narodu

Rozdział XII - Problemy bioetyki

Rozdział XIII - Kościół i problemy ekologii

Rozdział XIV - Nauka, kultura i edukacja świecka

Rozdział XV - Kościół i świeckie środki masowego przekazu

Rozdział XVI - Stosunki międzynarodowe. Problemy globalizacji i sekularyzacji

Z powyższego układu wyłania się obraz stanowiska, które swoim zakresem aspiruje do tego, aby ogarnąć możliwie najszersze spektrum funkcjonowania Kościoła we współczesnym świecie i stojących przed nim wyzwań.

Refleksja na temat konieczności wypracowania oficjalnego dokumentu prezentującego naukę społeczną Kościoła prawosławnego w Rosji na progu trzeciego tysiąclecia została zainicjowana już na początku lat 90. XX wieku. Jednak dopiero w grudniu 1994 roku, Święty Sobór Biskupów zobowiązał Świątobliwy Synod do powołania grupy roboczej w celu opracowania projektu stanowiska (Opredelenie..., 1994, §11). Wejście w życie decyzji soboru nastąpiło dwa lata później, na przełomie 1996 i 1997, gdy na kolejnych dwóch posiedzeniach Soboru Biskupów powołano liczący 26 osób zespół roboczy i zatwierdzono plan jego pracy. W skład grupy roboczej, oprócz biskupów, weszli duchowni i świeccy przedstawiciele wyższych szkół teologicznych i reprezentanci najważniejszych instytucji kościelnych. Do współpracy zaproszono także liczne grono reprezentantów świata nauki, a także przedstawicieli instytucji państwowych i organizacji społecznych. W okresie od stycznia 1997 do czerwca 2000 roku odbyło się trzydzieści posiedzeń grupy roboczej. Ostatecznie projekt dokumentu pod nazwą Podstawy koncepcji społecznej Rosyjskiego Kościoła Prawosławnego został zatwierdzony przez Świątobliwy Synod w dniu 19 lipca 2000 roku i wprowadzony do agendy najbliższego, zaplanowanego na sierpień jubileuszowego Soboru Biskupów (Žurnaly zasedaniâ Svâsennogo Sinoda..., 2000).

Uchwalenie tego ważnego dokumentu, niezależnie od jego późniejszych pozytywnych lub negatywnych ocen, formułowanych zarówno w środowiskach kościelnych, jak i pozakościelnych, było bez wątpienia jednym z najważniejszych wydarzeń w najnowszej historii rosyjskiego prawosławia. Można postawić tezę, że nie tylko otworzyło ono nowy rozdział w relacjach między Kościołem i państwem w nowych uwarunkowaniach społeczno-politycznych i gospodarczo-ekonomicznych po upadku ZSRR, lecz określiło zasadnicze kierunki aktywności Cerkwi w kształtowaniu religijno-kulturowego oblicza Rosji. W zakresie odpowiedzi Kościoła na wyzwania współczesności autorzy dokumentu, wśród których jedną z wiodących ról odegrał ówczesny metropolita smoleński i kaliningradzki, obecny zaś patriarcha Kościoła rosyjskiego Cyryl (Gundiajew), starano się na tyle, na ile było to wówczas możliwe, określić, czego państwo może, a czego nie powinno oczekiwać od Kościoła prawosławnego.

Bez wątpienia zarówno forma, jak i treść dokumentu, nie jest pozbawiona mankamentów. Wladislaw Arżanuchin, kierownik katedry religioznawstwa Uniwersytetu Rosyjskiego w Petersburgu, autora wielu prac poświęconych socjologii i współczesnemu prawosławiu rosyjskiemu, stwierdza:

„Dokument (...) jest pełny abstrakcyjnych uogólnień oraz wewnętrznych sprzeczności. (...) W koncepcji społecznej ani razu nie wspomniano o «społeczeństwie», w sensie społeczeństwa obywatelskiego, na próżno też szukać w niej refleksji o sprawiedliwości społecznej. Brak owych pojęć wydaje się nie tyle rezultatem nieświadomego zaniechania, co raczej wiernym odbiciem światopoglądu autorów doktryny, hierarchów i świeckich, którzy co prawda deklarują, że koncepcja nauki społecznej ma otworzyć prawosławie na świat nowoczesny, przygotować Cerkiew do sprostania wymaganiom nowego stulecia itd. ale w istocie konserwują porządek sięgający swoimi korzeniami czasów cara Piotra. (...) Doktryna nauki społecznej świadczy, że Kościół prawosławny chce kontynuować wertykalny system, w którym nie przewiduje się miejsca dla indywiduum i jego praw. Podstawą ładu ma być państwowy paternalizm, który ma zastąpić mrzonki w rodzaju praw człowieka itd. Władza - wedle hierarchów - ma być gwarantem etyki, prawa, wolności sumienia. Nic nie zwiastuje też, że w łonie Cerkwi oczekuje się aktywności wiernych. Cerkiew jest bowiem taka jak państwo: jest lud Boży, nad nim pasterze, ale nie ma społeczności świadomych i odpowiedzialnych za Kościół chrześcijan. A jeśli nie pojawi się wolny obywatel, a zarazem świadomy chrześcijanin, to jak może rozwijać się państwo czy Kościół? Nikt jednak nie martwi się tego rodzaju pytaniami" (Obywatel poza Cerkwia, 2000).

Pomimo głosów krytyki, płynących także ze środowisk kościelnych (Novik, 2000), przyjęcie Podstaw koncepcji społecznej RKP było potężnym impulsem w odnowie i rozwoju misji Kościoła prawosławnego w Rosji. Dyskurs wokół dokumentu, który był pierwszym tego rodzaju oficjalnym stanowiskiem Kościoła prawosławnego w odniesieniu do zagadnień społecznych w skali światowej, zwrócił uwagę najwyższych gremiów kościelnych na wykorzystywany dotąd w stopniu dość niewielkim ludzki potencjał intelektualny w łonie samej Cerkwi. Gotowość ludzi Kościoła do dialogu z przedstawicielami szeroko pojętego świata nauki, polityki i gospodarki na najbardziej trudne i nośne tematy społeczne przyniosła efekt w postaci wielu wspólnych przedsięwzięć o charakterze naukowo-badawczym i popularyzatorskim. Do takich kwestii należą niewątpliwie problemy bioetyczne i ekologiczne, które $\mathrm{w}$ dokumencie zostały poruszone w rozdziałach 
dwunastym i trzynastym. Oczywiście w wielu przypadkach stanowisko Kościoła, dla którego wyznacznikami są wskazania Pisma Świętego i dziedzictwo Tradycji, jest nieprzejednane i nie pozwala na kompromis. Przez przeciwników Kościoła jest to zwykle postrzegane jako niechęć do podjęcia dialogu w ogóle, co nie odpowiada prawdzie. Nie chodzi tutaj także o próbę narzucenia społeczeństwu przez Kościół określonego modelu życia. Kościół respektuje wolny wybór każdego człowieka, co wcale nie oznacza, że się z nim zgadza lub go popiera. Stojąc niewzruszenie na fundamencie wiary nie godzi się jednak na dyskredytację chrześcijańskich wartości i towarzyszącą mu naturalistyczną interpretacją ludzkiego bytu oraz otaczającej go rzeczywistości. Ten brak zgody należy traktować jako świadectwo wiary i postawę troski o autentyczną wolność religijną, która polega także, a dzisiaj nawet przede wszystkim, na nieprzymuszaniu do niewiary.

Podstawy koncepcji społecznej RKP należy traktować za akt normatywny Kościoła. W cytowanej już wyżej Preambule dokumentu czytamy:

„Niniejszy dokument, przyjęty przez Świątobliwy

Sobór Biskupów Rosyjskiego Kościoła Prawosław-

nego, stanowi wykład podstawowych norm Jego

nauki, które odnoszą się do kwestii relacji kościelno

-państwowych oraz ważnych współczesnych proble-

mów społecznych" (O dokumente, 2000).

$\mathrm{Z}$ powyższego wynika, że wyraźnie opiera się on na określonych podstawach zaliczanych przez Kościół prawosławny do prawd wiary, posiadających ścisły związek z nauką moralną i mających zastosowanie do konkretnych, zmiennych warunków społecznych. Oprócz niezmiennych zasad teologicznych zawiera on wskazania, które wynikają $\mathrm{z}$ adaptacji zasad wiary do istniejących warunków życia społecznego. Bynajmniej nie chodzi tutaj jednak o zmianę optyki Kościoła w zgodzie z ,duchem czasu”, lecz stworzenie przestrzeni dialogu. Dzięki takiemu podejściu zostaje zachowany zarówno element doktrynalny, jak i praktyczny, co umożliwia korzystanie z wytycznych moralnych w każdej sytuacji społeczno-politycznej i pozwala na zachowanie względnej autonomii rzeczywistości świeckiej i kościelnej, co w warunkach rosyjskich nigdy nie było łatwe. Można postawić tezę, że wytyczne zawarte w Podstawach koncepcji społecznej RKP idą we właściwym kierunku w wyznaczaniu granic, których Państwo w stosunku do Kościoła nie może przekraczać. Oczywiście, jak słusznie zauważa cytowany wyżej Władisław Arżanuchin, zdaniem autorów dokumentu państwo jest wartością samą w sobie, podstawą ładu społecznego jest państwowy paternalizm, a władza ma być gwarantem etyki, prawa, wolności sumienia. Nie jest to jednak nic nadzwyczajnego, biorąc pod uwagę specyficzne rosyjskie uwarunkowania historyczne, kulturowe i społeczne. Jego diagnoza, iż ,doktryna nauki społecznej świadczy, że Kościół prawosławny (...) nie przewiduje miejsca dla indywiduum i jego praw" wydaje się przesadzona (Obywatel poza Cerkwia, 2000).

Bez wątpienia, twórcy i sygnatariusze dokumentu, dołożyli starań, aby diagnozy i wytyczne zawarte w Podstawach koncepcji społecznej RKP były zgodne z nauką
Ewangelii i jednocześnie nieoderwane od historyczno-kulturowego kontekstu współczesności w sensie globalnym, a także specyficznej rosyjskiej rzeczywistości.

„Charakter dokumentu jest uwarunkowany koniecznością zwrócenia uwagi na całość potrzeb Rosyjskiego Kościoła Prawosławnego w Jego Pełni, na przestrzeni długiego okresu historycznego, na terytorium kanonicznym Patriarchatu Moskiewskiego i poza jego granicami. Dlatego jego podstawowym przedmiotem zainteresowania są fundamentalne kwestie teologiczne i kościelno-społeczne, a także te aspekty życia państwowego i społecznego, które były i nadal pozostają aktualne dla Pełni Kościoła u schyłku XX wieku i w najbliższej przyszłości” ( $O$ dokumente, 2000).

Z powyższego wynika, że zasad dokumentu, według zamysłu jego twórców, nie można traktować jak czysto teoretyczną doktrynę. Jest ona raczej zbiorem twierdzeń i zasad, w świetle których można i należy poszukiwać rozwiązań problemów dotyczących współżycia społecznego w zgodzie z Pismem Świętym i Tradycją Kościoła, która w prawosławiu jest normą wiary. Celem niniejszej publikacji jest zapoznanie polskiego czytelnika z treścią rozdziału dwunastego i trzynastego Podstaw koncepcji społecznej RKP, które odnoszą się do problematyki bioetycznej (Problemy bioetiki, 2000) i ekologicznej (Cerkov' i problemy ekologii, 2000). W rozdziale „Problemy bioetyki" w poszczególnych punktach poruszone zostały kwestie związane z: rozwojem technologii biomedycznych (1), aborcją (2), stosowaniem środków antykoncepcyjnych (3), medycznym wspomaganiem prokreacji (4), ingerencjami genetycznymi i badaniami prenatalnymi (5), klonowaniem (6), transplantacjami (7), opieką paliatywnej i eutanazją (8), problematyką zmiany płci i stosunku do nienormatywnych orientacji seksualnych, w szczególności do homoseksualizmu. W rozdziale trzynastym, autorzy dokumentu poświęcają wiele uwagi omówieniu zagadnień związanych z: odpowiedzialnością człowieka za środowisko naturalne (1), relacjami między człowiekiem a przyrodą (2), kryzysem ekologicznym (3), zanieczyszczeniem środowiska i eksploatacją zasobów naturalnych (4) oraz podkreśleniem związku między ekologią i antropologią (5). Warto podkreślić, że prezentowany niżej przekład fragmentów Podstaw koncepcji społecznej RKP odnoszących się do teologicznej recepcji problemów bioetycznych i ekologicznych jest pierwszym takim tłumaczeniem na język polski.

\section{Podstawy społecznej koncepcji Rosyjskiego Kościoła Prawosławnego}

\section{Rozdział XII - Problemy bioetyki}

1. Gwałtowny rozwój technologii biomedycznych, które aktywnie ingerują w życie współczesnego człowieka od momentu narodzin do śmierci, a także niemożność 
uzyskania odpowiedzi na pojawiające się przy tej okazji problemy natury moralnej w ramach tradycyjnej etyki medycznej, są przyczyną poważnego zaniepokojenia w społeczeństwie. Ludzkie próby, aby postawić siebie w miejsce Boga, zmieniając i ,ulepszając” Jego stworzenie według własnego uznania, mogą przynieść ludzkości nowe obciążenia i cierpienia. Rozwój technologii biomedycznych znacznie wyprzedza zrozumienie możliwych duchowych, moralnych i społecznych konsekwencji ich niekontrolowanego wykorzystania, co nie może nie wywołać głębokiej troski duszpasterskiej Kościoła. Kościół, formułując swoje stanowisko wobec szeroko dyskutowanych we współczesnym świecie problemów bioetyki, przede wszystkim zaś tych, które są związane $\mathrm{z}$ bezpośrednim oddziaływaniem na człowieka, wychodzi z opartej na Bożym Objawieniu idei życia jako bezcennego daru Bożego, niezbywalnej wolności i wynikającej z podobieństwa do Boga godności ludzkiej osoby, powołanej „do nagrody, wynikającej z niebiańskiego powołania przez Boga w Chrystusie Jezusie" (Flp 3, 14), do osiągnięcia doskonałości Ojca Niebiańskiego (Mt 5, 48) i przebóstwienia, czyli uczestnictwa w Boskiej naturze $(2 \mathrm{P} 1,4)$.

2. Od czasów starożytnych Kościół uważa zamierzone przerwanie ciąży (aborcję) za ciężki grzech. Reguły kanoniczne stawiają między aborcją i zabójstwem znak równości. Podstawą takiej oceny jest przekonanie, iż zaistnienie istoty ludzkiej jest darem Bożym. Dlatego już od momentu poczęcia każde naruszenie prawa do życia osoby ludzkiej jest przestępstwem.

Psalmista opisuje rozwój płodu w łonie matki jako akt twórczy Boga: „Ty bowiem ukształtowałeś moje wnętrze, utkałeś mnie w łonie matki. (...) Moje kości nie były Ci obce, gdy byłem tworzony w ukryciu, tkany w głębi łona. Twoje oczy widziały mój początek" (Ps. 138, 13. 1516). O tym także zaświadcza Hiob w słowach, w których zwraca się do Boga: „Twoje ręce mnie uczyniły, ukształtowały z każdej strony (...). Czy nie przelałeś mnie jak mleko i nie stężałem jak ser? W skórę i ciało mnie odziałeś, powiązałeś kośćmi i żyłami, obdarzyłeś mnie życiem i łaską, a opieka swą chroniłeś me tchnienie. (...) Kazałeś mi wyjść z łona matki” (Hi 10, 8. 10-12. 18). „Zanim w łonie cię ukształtowałem - znałem cię, zanim się urodziłeś - poświęciłem cię" (Jer 1, 5-6) - powiedział Pan do proroka Jeremiasza. „Nie zabijaj dziecka wywołując poronienie" - ten nakaz znajduje się wśród najważniejszych Bożych przykazań w Nauce dwunastu Apostołów, jednym z najstarszych zabytków chrześcijańskiego piśmiennictwa. „Kobieta, zażywająca środków powodujących poronienie dopuszcza się zbrodni i odpowie za to przed Bogiem. (...) Płód w łonie matki jest istotą żywą, o którą troszczy się Bóg” - pisał Atenagoras, apologeta z II wieku. „Ten, który ma być człowiekiem, jest już człowiekiem" - twierdził na przełomie II i III wieku Tertulian. „Kobieta, która rozmyślnie niszczy płód, podlega takiej karze, jak za zabójstwo. (...) Ci, którzy dostarczają środków wywołujących poronienie, są zabójcami, podobnie jak ci, którzy te trucicielskie, zabijające płód środki przyjmują" - stwierdzono w 2. i 8. regule kanonicznej autorstwa świętego Bazylego
Wielkiego, które zostały włączone do księgi kanonów Kościoła prawosławnego i potwierdzone przez 91. kanon VI Soboru Powszechnego. Święty Bazyli precyzuje przy tym, że ciężar przewinienia nie zależy od zaawansowania stanu brzemienności: „Nie do nas należy dochodzenie, czy płód był już ukształtowany, czy jeszcze bezkształtny”. Święty Jan Chryzostom określił zaś tych, którzy dokonują aborcji mianem „gorszych od zabójców”.

Rozpowszechnienie i usprawiedliwienie aborcji we współczesnym społeczeństwie Kościół traktuje jako zagrożenie dla przyszłości rodzaju ludzkiego i wyraźny przejaw moralnej degradacji. Wierność biblijnej i patrystycznej nauce o świętości i bezcennej wartości ludzkiego życia od samych jego początków stoi w jawnej sprzeczności z uznaniem „wolności wyboru” kobiety do decydowania o losie płodu. Ponadto aborcja stanowi poważne zagrożenie dla zdrowia fizycznego i psychicznego matki. Kościół niezmiennie uważa również za swój obowiązek obronę najbardziej bezbronnych i pozostających z zależności od innych istot ludzkich, którymi są nienarodzone dzieci. Bez względu na okoliczności Kościół prawosławny nie może udzielić błogosławieństwa na dokonanie przerwanie ciąży. Kościół nie odrzuca jednak kobiet, które aborcji dokonały, ale wzywa je do pokuty i przezwyciężenia zgubnych konsekwencji grzechu poprzez modlitwę i przyjęcie epitemii, a następnie uczestnictwo w zbawiennych Sakramentach. W przypadkach, gdy istnieje bezpośrednie zagrożenie życia matki związane z utrzymaniem ciąży, w szczególności zaś, gdy posiada ona inne dzieci, w praktyce duszpasterskiej zaleca się okazanie wyrozumiałości. W takich okolicznościach kobieta, która dokonała przerwania ciąży, nie podlega odłączeniu od uczestnictwa w komunii eucharystycznej we wspólnocie Kościoła. Jej uczestnictwo jest jednak obwarowane wypełnieniem przez nią indywidualnej pokutnej reguły modlitewnej, którą ustala kapłan przyjmujący spowiedź. Walka z aborcją, na dokonanie której czasami decydują się kobiety z powodu skrajnej biedy i bezradności, wymaga od Kościoła i społeczeństwa opracowania skutecznej strategii ochrony macierzyństwa, a także zapewnienia warunków do adopcji dzieci, których matka z jakiegoś powodu nie może samodzielnie wychować.

Odpowiedzialność za grzech zabójstwa nienarodzonego dziecka, na równi z matką ponosi także ojciec, który godzi się na przeprowadzenie aborcji. Jeżeli aborcji dokonuje żona bez wiedzy męża, może to być podstawą do rozwodu. Grzech obciąża także duszę lekarza, który dokonuje aborcji. Kościół wzywa państwo do uznania prawa pracowników służby zdrowia do odmowy przeprowadzenia aborcji ze względu na sprzeciw sumienia. Nie można uznać za normalną sytuacji, w której odpowiedzialność prawna lekarza za śmierć matki jest niewspółmiernie większa niż odpowiedzialność za spowodowanie śmierci płodu, co zachęca lekarzy, a za ich pośrednictwem także pacjentów, do aborcji. Lekarz powinien wykazać się maksymalną odpowiedzialnością za postawioną diagnozę, która może skłonić kobietę do przerwania ciąży. Jednocześnie lekarz, który jest człowiekiem wierzącym, jest zobowiązany do 
przeprowadzenia skrupulatnej analizy swoich działań, które wynikają ze wskazań medycznych, z nakazami chrześcijańskiego sumienia.

3. Oceny religijno-moralnej wymaga również problem antykoncepcji. Niektóre środki, które zapobiegają poczęciu, w rzeczywistości mają działanie aborcyjne, sztucznie przerywając życie zarodka na najwcześniejszych etapach jego rozwoju. Orzeczenia dotyczące aborcji mają zatem zastosowanie również do nich. Inne środki, których działania nie są związane z przerwaniem życia już poczętego, w żadnym wypadku nie mogą być utożsamiane z aborcją. Chrześcijańscy małżonkowie, określając swój stosunek do antykoncepcji nieaborcyjnej, powinni jednak pamiętać, że przedłużenie gatunku ludzkiego jest jednym z głównych priorytetów małżeństwa, które zostało ustanowione przez Boga. Rozmyślne uchylanie się od prokreacji z pobudek egoistycznych deprecjonuje małżeństwo i bez wątpienia jest grzechem.

Jednocześnie małżonkowie są odpowiedzialni przed Bogiem za godziwe wychowanie dzieci. Jedną z dróg realizacji odpowiedzialnego stosunku do prokreacji jest powstrzymanie się przez pewien czas od stosunków płciowych. Koniecznie jednak trzeba przy tym pamiętać o słowach apostoła Pawła skierowanych do chrześcijańskich małżonków: „Nie strońcie jedno od drugiego, chyba że za obopólną zgodą i na pewien czas, abyście mogli oddać się modlitwie. Potem znowu bądźcie razem, aby szatan nie kusił was z powodu waszego nieopanowania" (1 Kor 7, 5). Oczywiście małżonkowie powinni razem podejmować decyzje w tej kwestii, korzystając z porady spowiednika. Ten ostatni powinien zaś z duszpasterską rozwagą uwzględniać konkretne warunki życia pary małżeńskiej, ich wiek, zdrowie, stopień dojrzałości duchowej i wiele innych okoliczności, rozróżniając między tymi, którzy potrafią sprostać wysokim wymaganiom abstynencji, a tymi, którym nie jest to „dane” (Mt 19, 11), przede wszystkim dbając przy tym o zachowanie i umocnienie rodziny.

Święty Synod Rosyjskiego Kościoła Prawosławnego W swoim stanowisku z dnia 28 grudnia 1998 roku zalecił kapłanom pełniącym posługę duszpasterską ,,niedopuszczalność stosowania przymusu lub nakłaniania wiernych, wbrew ich woli, do (...) rezygnacji z małżeńskiego współżycia w związku", a także przypomniał duszpasterzom o potrzebie ,przestrzegania w szczególny sposób czystości i zachowania wyjątkowej duszpasterskiej ostrożności przy omawianiu z wiernymi kwestii związanych z różnymi aspektami ich życia rodzinnego".

4. Zastosowanie nowych metod biomedycznych w wielu przypadkach pozwala przezwyciężyć cierpienie z powodu niepłodności. Jednocześnie rozszerzenie zakresu ingerencji technicznych $\mathrm{w}$ proces powstawania życia ludzkiego jawi się jako zagrożenie dla integralności duchowej i zdrowia fizycznego osoby. Zagrożone są również relacje międzyludzkie leżące u podstaw organizacji społeczeństwa już od czasów starożytnych. Wraz z rozwojem wspomnianych technologii wiąże się także upowszechnianie ideologii tzw. praw reprodukcyjnych, która jest obecnie promowana na poziomie krajowym i międzynarodowym.
Ten system poglądów zakłada pierwszeństwo seksualnej i społecznej realizacji osoby ludzkiej przed troską o przyszłość dziecka, o duchowe i fizyczne zdrowie społeczeństwa, o jego stabilność moralną. Świat stopniowo rozwija podejście do życia ludzkiego jak produktu, który można wybrać według własnych upodobań i którym można zarządzać tak samo jak wartościami materialnymi.

W modlitwach obrzędu zawarcia sakramentu małżeństwa Kościół prawosławny daje wyraz swej wierze, iż wzbudzanie potomstwa jest wprawdzie pożądanym owocem legalnie zawartego małżeństwa, jednakże nie jego celem jedynym. Wraz z prośbą o „owoc łona ku pożytkowi” zabiega dla małżonków o dary nieprzemijającej wzajemnej miłości, czystości oraz ,jednomyślności dusz i ciał”. Dlatego Kościół nie może uznać za moralnie usprawiedliwione działań zmierzających do uzyskania potomstwa, które nie są zgodne z zamysłem Stwórcy życia. Jeśli mąż lub żona nie są w stanie począć dziecka, a terapeutyczne i chirurgiczne metody leczenia niepłodności nie pomagają małżonkom, powinni oni z pokorą zaakceptować swoją bezdzietność jako szczególne życiowe powołanie. W takich przypadkach zalecenia duszpasterskie powinny uwzględniać możliwość adopcji dziecka za obopólną zgodą małżonków. Dopuszczalnym środkiem pomocy medycznej może być zabieg zapłodnienia komórkami płciowymi męża [inseminacja - przyp. tłum.] i ile nie narusza on integralności związku małżeńskiego, nie różni się zasadniczo od poczęcia w sposób naturalny i ma miejsce w kontekście relacji małżeńskich.

Manipulacje związane z donacją komórek płciowych naruszają integralność osoby ludzkiej i wyjątkowość relacji małżeńskiej, dopuszczając do wtargnięcia weń osoby trzeciej. Poza tym, praktyka ta wspiera nieodpowiedzialne podejście do ojcostwa lub macierzyństwa, które zostaje z pełna świadomością zwolnione od wszelkich zobowiązań wobec tych, którzy są „ciałem z ciała” anonimowych dawców. Wykorzystanie materiału dawcy podważa fundamenty relacji rodzinnych, ponieważ zakłada, że dziecko, oprócz „,społecznych”, ma również tak zwanych biologicznych rodziców. „Macierzyństwo zastępcze”, czyli umieszczenie zapłodnionej komórki jajowej w łonie kobiety, która po porodzie zwraca dziecko „klientom”, jest nienaturalne i moralnie niedopuszczalne nawet wtedy, gdy odbywa się to na zasadach non-profit. Zastosowanie tej techniki skutkuje destrukcją głębokiej emocjonalnej więzi i duchowej bliskości powstałej między matką a dzieckiem podczas ciąży. „Macierzyństwo zastępcze” traumatyzuje zarówno kobietę brzemienną, której uczucia macierzyńskie są deptane, jak i dziecko, które w późniejszym okresie może doświadczać kryzysu tożsamości. Z prawosławnego punktu widzenia niedopuszczalne moralnie są również wszystkie odmiany zapłodnienia pozaustrojowego (poza ciałem), które polegają na pozyskiwaniu, konserwacji i celowym niszczeniu zarodków „nadliczbowych”. Moralna ocena aborcji, która jest potępiana przez Kościół, opiera się także na uznaniu godności ludzkiego zarodka.

Zapłodnienie samotnych kobiet za pomocą komórek zarodkowych dawcy lub realizacja ,praw reprodukcyj- 
nych" samotnych mężczyzn, a także osób o tak zwanej niestandardowej orientacji seksualnej, pozbawia dziecko, które się narodzi, prawa do posiadania matki i ojca. Zastosowanie metod reprodukcyjnych poza kontekstem pobłogosławionej przez Boga rodziny jest formą walki z Bogiem, prowadzonej pod pozorem ochrony autonomii człowieka i opacznie rozumianej wolności osoby ludzkiej.

5. Znaczną część wszystkich ludzkich dolegliwości stanowią choroby dziedziczne. Rozwój genetycznych metod diagnostyki i leczenia może pomóc w zapobieganiu takim chorobom i złagodzić cierpienia wielu ludzi. Należy jednak pamiętać, że anomalie genetyczne są często konsekwencjami amnezji zasad moralnych, skutkiem deprawacji sposobu życia, w wyniku których cierpi także potomstwo. Grzeszne skalanie natury ludzkiej zostaje pokonane przez wysiłek duchowy. Jeśli zaś, z coraz większą mocą, z pokolenia na pokolenie, życie potomstwa znajduje się pod władzą nieprawości, to wypełniają się słowa Pisma Świętego: „straszny jest koniec niesprawiedliwego” (Mdr 3, 19). I na odwrót: „Szczęśliwy, kto się boi Pana i miłuje jego przykazania. Jego potomstwo będzie potężne na ziemi - pokolenie prawych otrzyma błogosławieństwa" (Ps 111, 1-2). Wynika z tego, że badania w dziedzinie genetyki tylko potwierdzają prawa duchowe, które przed wiekami zostały objawione ludzkości przez słowo Boże.

Kościół, zwracając uwagę ludzi na moralne przyczyny chorób, jednocześnie pozytywnie odnosi się do wysiłków lekarzy, które mają na celu leczenie chorób dziedzicznych. Celem manipulacji genetycznych nie powinno być jednak sztuczne „udoskonalenie” rodzaju ludzkiego oraz ingerencja w Boży plan dotyczący człowieka. Dlatego terapia genowa może być przeprowadzana tylko za zgodą pacjenta lub jego prawnych przedstawicieli i wyłącznie z przyczyn medycznych. Terapia genowa komórek płciowych jest niezwykle niebezpieczna, ponieważ wiąże się ze zmianą genomu (zestawu cech dziedzicznych) w wielu pokoleniach, co może prowadzić do nieprzewidywalnych konsekwencji w postaci nowych mutacji oraz destabilizacji równowagi między społecznością ludzką i środowiskiem.

Sukcesy w rozszyfrowaniu ludzkiego genomu czynią realnymi warunki do wykonywania zakrojonych na szeroką skalę testów genetycznych w celu pozyskania informacji na temat unikalnych naturalnych cech każdego człowieka, a także jego predyspozycji do zapadania na określone schorzenia. Stworzenie ,paszportu genetycznego”, przy rozsądnym wykorzystaniu uzyskanych informacji, pomogłoby w odpowiednim czasie zapobiec rozwojowi chorób, których wystąpienie byłoby możliwe u konkretnego człowieka. Niestety istnieje jednak realne ryzyko niewłaściwego wykorzystania informacji genetycznych, które mogą posłużyć różnym formom dyskryminacji. Ponadto posiadanie informacji o dziedzicznej predyspozycji do poważnych chorób może stać się przytłaczającym obciążeniem psychicznym. Dlatego identyfikacja genetyczna i testy genetyczne mogą być wykonywane wyłącznie na podstawie poszanowania wolności osoby ludzkiej.

Ambiwalentny charakter mają także prenatalne (przedporodowe) metody diagnostyczne, które pozwalają na rozpoznanie choroby dziedzicznej już we wczesnych stadiach rozwoju płodu. Niektóre z tych metod mogą zagrażać życiu i integralności poddawanego badaniu zarodka lub płodu. Identyfikacja nieuleczalnej lub trudnej do wyleczenia choroby genetycznej nierzadko staje się zachętą do przerwania poczętego życia. Zdarzały się przypadki, że rodzice byli nawet $\mathrm{z}$ tego tytułu poddawani presji. Diagnostykę prenatalną można uznać za moralnie uzasadnioną, jeśli ma ona na celu leczenie rozpoznanych dolegliwości na jak najwcześniejszym etapie, a także przygotowanie rodziców do objęcia chorego dziecka specjalną opieką. Każdy człowiek ma prawo do życia, miłości i opieki, niezależnie od tego, na jakie choroby cierpi. Według Pisma Świętego sam Bóg jest „obrońcą słabych” (Jd 9, 11). Apostoł Paweł naucza, aby „wspierać słabych” (Dz 20, 35; 1 Tes 5, 14). Porównując Kościół do ludzkiego ciała zauważa on, że „o wiele bardziej potrzebne są członki (...), które uchodzą za słabsze", a mniej doskonali potrzebują większej troski (1 Kor 22, 24. 24). Stosowanie prenatalnych metod diagnostycznych w celu wyboru pożądanej przez rodziców płci dziecka jest całkowicie niedopuszczalne.

6. Przeprowadzone przez naukowców klonowanie (uzyskanie kopii genetycznych) zwierząt generuje pytanie o dopuszczalność i możliwe konsekwencje klonowania człowieka. Realizacja tego budzącego sprzeciw wielu ludzi na całym świecie zamierzenia może stać się destrukcyjna dla społeczeństwa. Klonowanie, w jeszcze większym stopniu niż inne technologie reprodukcyjne, stwarza możliwość manipulacji cechami genetycznymi osoby ludzkiej i przyczynia się do jej dalszej deprecjacji. Człowiek nie ma prawa domagać się roli twórcy istot do siebie podobnych ani dokonywać wyboru wzorców genetycznych, z góry określając ich cechy indywidualne według własnego uznania. Idea klonowania jest niezaprzeczalnie prowokacyjnym wyzwaniem rzuconym samej naturze człowieka oraz złożonemu weń obrazu Bożego, którego niezbywalną częścią jest wolność i wyjątkowość osoby ludzkiej. „Powielanie” ludzi o ustalonych parametrach może wydawać się pożądane tylko dla wyznawców ideologii totalitarnych.

Klonowanie człowieka jest zdolne wypaczyć naturalne podstawy prokreacji, pokrewieństwa, macierzyństwa i ojcostwa. Dziecko może zostać siostrą swojej matki, bratem ojca lub córką dziadka. Psychologiczne konsekwencje klonowania są niezwykle niebezpieczne. Człowiek, który przyszedł na świat w wyniku takiej procedury, może nie czuć się osobą niezależną, a jedynie „kopią” jakichś żyjących obecnie lub wcześniej ludzi. Należy również liczyć się z tym, że „efektem ubocznym” eksperymentów z klonowaniem człowieka byłoby całe mnóstwo martwych ludzkich istot, i najprawdopodobniej, ogromna ilość potomstwa, które pomimo tego, iż się narodziło, nie było zdolne do dalszego życia. Niemniej jednak klonowanie wyizolowanych komórek i tkanek organizmu nie stanowi naruszenia godności osoby ludzkiej, a w niektórych przypadkach jest przydatne w praktyce biologicznej i medycznej.

7. Współczesna transplantologia (teoria i praktyka przeszczepiania narządów i tkanek) pozwala zapewnić skuteczną pomoc wielu pacjentom, którzy wcześniej by- 
liby skazani na nieuchronną śmierć lub ciężką niepełnosprawność. Jednocześnie rozwój tej gałęzi medycyny, odpowiadając na zwiększone zapotrzebowanie na niezbędne narządy, stwarza pewne problemy natury moralnej i może stanowić zagrożenie dla społeczeństwa. A zatem pozbawiona skrupułów propaganda dawstwa i komercjalizacja działań związanych z przeszczepami stwarzają przesłanki do handlu częściami ludzkiego ciała, zagrażając życiu i zdrowiu ludzi. Kościół uważa, że ludzkie narządy nie mogą być traktowane jak obiekt kupna i sprzedaży. Przeszczep organu od żyjącego dawcy może opierać się tylko na jego dobrowolnym poświęceniu w celu ratowania życia drugiego człowieka. W tym przypadku zgoda na eksplantację (pobranie narządu) jest wyrazem miłości i współczucia. Potencjalny dawca powinien zostać w pełni poinformowany o możliwych konsekwencjach operacji pobrania narządu dla jego zdrowia. Eksplantacja, która bezpośrednio zagraża życiu dawcy, jest moralnie niedopuszczalna. Najczęstszą praktyką jest pobieranie organów od osób niedawno zmarlych. W takich sytuacjach należy unikać niejasności przy ustalaniu momentu śmierci. Niedopuszczalne jest skracanie życia jednego człowieka, w tym także poprzez rezygnację z procedur podtrzymujących jego życie, w celu przedłużenia życia innego człowieka.

Opierając się na Boskim Objawieniu, Kościół wyznaje wiare $\mathrm{w}$ cielesne zmartwychwstanie zmarłych (Iz 26, 19; Rz 8, 11; 1 Kor 15, 42-44. 52-54; Flp 3, 2). W obrzędzie chrześcijańskiego pogrzebu Kościół wyraża należny szacunek ciału zmarłego człowieka. Pośmiertna donacja narządów i tkanek może być jednak przejawem miłości, wykraczającym poza wydarzenie śmierci. Tego rodzaju dar lub oświadczenie woli nie mogą być uważane za obowiązek człowieka. Dlatego dobrowolna zgoda dawcy za życia jest warunkiem legalności i moralnej dopuszczalności eksplantacji. W przypadku, gdy lekarze nie dysponują wiedzą na temat decyzji potencjalnego dawcy, są zobowiązani do poczynienia wyjaśnień w kwestii intencji osoby umierającej lub zmarłej, kontaktując się w razie potrzeby z jej krewnymi. Tak zwaną zasadę zgody domniemanej potencjalnego dawcy na pobranie narządów i tkanek jego ciała, która została prawnie usankcjonowana w kilku krajach, Kościół uważa za przejaw niedopuszczalnego naruszenia wolności człowieka.

Narządy i tkanki dawcy są adaptowane przez organizm przyjmującego je człowieka (biorcy), włączając się w sferę jego duchowo-cielesnej osobowej jedności. Dlatego w żadnym wypadku nie może być usprawiedliwiony moralnie taki przeszczep, który mógłby stanowić zagrożenie dla indywidualnej tożsamości biorcy, uwzględniając jego wyjątkowość jako osoby i reprezentanta gatunku. Jest szczególnie ważne, aby pamiętać o tym fakcie przy podejmowaniu decyzji dotyczących kwestii związanych z przeszczepem tkanek i narządów pochodzenia zwierzęcego.

Za bezwzględnie niedopuszczalne Kościół uważa stosowanie metod tak zwanej terapii fetalnej, polegającej na pobieraniu oraz wykorzystywaniu tkanek i narządów ludzkich zarodków, które zostały poddane aborcji na różnych etapach rozwoju prenatalnego, w celu leczenia różnych dolegliwości chorobowych i „odmładzania” organizmu. Potępiając aborcję jako grzech śmiertelny, Kościół nie znajduje uzasadnienia dla stosowania tej praktyki nawet wtedy, jeśli po destrukcji poczętego życia ludzkiego ktoś, być może, odniesie z tego tytułu zdrowotną korzyść. Taka praktyka, niechybnie przyczyniając się do jeszcze szerszego rozpowszechnienia i komercjalizacji aborcji (nawet wtedy, jeśli jej skuteczność, obecnie hipotetyczna, zostałaby naukowo udowodniona), stanowi przykład rażącego braku moralności i ma charakter przestępczy.

8. Praktyka pobierania narządów ludzkich nadających się do transplantacji, a także rozwój technik reanimacji generują problem prawidłowego określenia momentu śmierci. Wcześniej, za kryterium jej nadejścia uważano nieodwracalne zatrzymanie oddechu i krążenia. Obecnie, dzięki ulepszeniu technik reanimacyjnych, wspomniane funkcje życiowe mogą być jednak sztucznie podtrzymywane przez długi czas. $\mathrm{W}$ ten sposób moment śmierci zmienia się w proces umierania, który jest zależny od decyzji lekarza, co nakłada na współczesną medycynę jakościowo nową odpowiedzialność.

W Piśmie Świętym śmierć jest określana jako oddzielenie duszy od ciała (Ps 145, 4; Łk 12, 20). W ten sposób, o kontynuacji życia można mówić dopóty, dopóki organizm jest aktywny jako całość. Przedłużanie życia za pomocą sztucznych środków w sytuacji, gdy faktycznie działają tylko niektóre narządy, nie może być uważane za obligatoryjne i pożądane zadanie medycyny we wszystkich przypadkach. Opóźnianie godziny śmierci niekiedy tylko przedłuża cierpienia chorego człowieka, pozbawiając go prawa do godnej, „bez zawstydzenia i spokojnej” śmierci, o którą prawosławni chrześcijanie proszą Pana w modlitwach. Kiedy aktywna terapia staje się niemożliwa, należy ją zastąpić opieką paliatywną (eliminacja bólu, pielęgnacja chorego, wsparcie społeczne i psychologiczne) i troską duszpasterską. Wszystko to ma na celu zapewnienie zakończenia życia w sposób autentycznie ludzki, ogrzany miłością i miłosierdziem.

Prawosławne pojmowanie zakończenia życia „,bez zawstydzenia" obejmuje przygotowanie do śmierci, która jest uważana za duchowo znaczący etap w życiu człowieka. Otoczony chrześcijańską troską chory człowiek, w ostatnich dniach swej doczesnej egzystencji, jest w stanie doświadczyć błogosławionej przemiany związanej z nowym zrozumieniem drogi, którą przeszedł, i pokajannym stanięciem w obliczu wieczności. Cierpliwa opieka nad chorym, zarówno dla krewnych umierającego, jak i pracowników medycznych, staje się zaś okazją do służenia Samemu Panu, zgodnie ze słowami Zbawiciela: „Co uczyniliście jednemu z tych braci Moich najmniejszych, Mnie uczyniliście" (Mt 25:40). Ukrywanie przed pacjentem informacji o poważnym stanie zdrowia pod pretekstem troski o jego komfort psychiczny często pozbawia umierającego możliwości świadomego przygotowania się do śmierci i pociechy duchowej, które uzyskuje przez uczestnictwo w Sakramentach Kościoła, a także wprowadza nieufność w relacje z krewnymi i lekarzami. 
Poprzedzające śmierć cierpienia fizyczne nie zawsze są skutecznie eliminowane przez zastosowanie środków przeciwbólowych. Wiedząc o tym, Kościół w takich przypadkach zwraca się do Boga z modlitwą: „Uwolnij Twego sługę od tego bólu nie do zniesienia i trzymającej go gorzkiej niemocy, i daj mu odpoczynek tam, gdzie są duchy sprawiedliwych" (Euchologion. Modlitwa za człowieka, który dlugo cierpi). Tylko jeden Pan jest władcą życia i śmierci (1 Krl 2, 6). ,W Jego ręce jest tchnienie wszystkiego, co żyje i duch każdego człowieka" (Hi 12, 10). Dlatego Kościół, pozostając wierny przykazaniu Bożemu „Nie zabijaj" (Wj 20,13), nie może uznać za moralnie dopuszczalne rozpowszechnione obecnie $\mathrm{w}$ świeckim społeczeństwie próby zalegalizowania tak zwanej eutanazji, czyli zamierzonego uśmiercania ludzi terminalnie chorych (także na ich życzenie). Prośba chorego o przyspieszenie śmierci jest niekiedy spowodowana stanem depresyjnym, który pozbawia go możliwości prawidłowej oceny sytuacji. Uznanie legalności eutanazji doprowadziłoby do zdeprecjonowania godności i wypaczenia obowiązków zawodowych lekarza, powołanego do zachowania, a nie skracania życia. „Prawo do śmierci" może łatwo przerodzić się w zagrożenie dla życia pacjentów, na leczenie których nie wystarcza środków pieniężnych.

Eutanazja jest zatem formą zabójstwa lub samobójstwa, w zależności od tego, czy pacjent aktywnie w niej uczestniczy. W drugim w wymienionych przypadków do eutanazji mają zastosowanie odpowiednie przepisy kanoniczne, zgodnie z którymi samobójstwo dobrowolne i okazana $\mathrm{w}$ jego popełnieniu pomoc, są uważane za grzech ciężki. Samobójca, który świadomie „dopuścił się swego czynu pod wpływem zniewagi albo obelgi ze strony ludzi" nie jest godny chrześcijańskiego pochówku i liturgicznego upamiętnienia (kanon 14 Tymoteusza Aleksandryjskiego). Jeśli samobójca nieświadomie odebrał sobie życie „tracąc rozum", czyli uczynił to z powodu choroby psychicznej, modlitwa kościelna za niego jest dozwolona po przeprowadzeniu dochodzenia $\mathrm{w}$ tej sprawie przez biskupa. Jednocześnie koniecznie należy pamiętać o tym, że wraz z samobójcą winę za jego czyn ponoszą nierzadko ludzie z jego otoczenia, którzy okazali się niezdolni do skutecznego współczucia i okazania mu miłosierdzia. Kościół wraz z apostołem Pawłem wzywa: „Jedni drugich ciężary noście, i tak wypełnicie prawo Chrystusa" (Gal 6,2).

9. Pismo Święte i nauka Kościoła jednoznacznie potępiają homoseksualne stosunki płciowe, widząc $\mathrm{w}$ nich grzeszne wypaczenie stworzonej przez Boga ludzkiej natury.

„Mężczyzna, który współżyje z mężczyzną, tak jak współżyje się z kobietą, dopuszcza się obrzydliwości”" (Kpł 20,13). Biblia mówi o surowej karze, jakiej zostali poddani przez Boga mieszkańcy Sodomy (Rdz 19, 1-29), zgodnie z interpretacją świętych ojców właśnie za grzech pederastii. Apostoł Paweł, charakteryzując stan moralny świata pogańskiego, wymienia stosunki homoseksualne wśród „haniebnych namiętności” i „nieprzyzwoitości”, które kalają ludzkie ciało: „Ich kobiety zamieniły współżycie zgodne $\mathrm{z}$ naturą na przeciwne naturze. Podobnie mężczyźni porzucili zgodne z naturą współżycie z kobietą i zapałali żądzą jedni ku drugim. Mężczyźni z mężczyznami dopuszczają się haniebnych czynów i dlatego sami na sobie ponoszą karę należną za zboczenie" (Rz 1, 2627). „Nie łudźcie się! (...) Ani rozwiąźli, ani ci, którzy współżyją z mężczyznami, (...) nie odziedziczą Królestwa Boga" - pisał apostoł do mieszkańców rozpustnego Koryntu (1 Kor 6, 9-10). Tradycja patrystyczna potępia równie wyraźnie i zdecydowanie wszelkie przejawy homoseksualizmu. Nauka Dwunastu Apostołów, dzieła świętych Bazylego Wielkiego, Jana Chryzostoma, Grzegorza z Nyssy, błogosławionego Augustyna i reguły kanoniczne autorstwa świętego Jana Postnika dają wyraz niezmiennej nauki Kościoła, według której związki homoseksualne są grzeszne i godne potępienia. Ludzie, którzy są w nie uwikłani, nie mają prawa być osobami duchownymi (kanon 7 Bazylego Wielkiego, kanon 4 Grzegorza z Nyssy, kanon 30 Jana Postnika). Święty Maksym Grek, zwracając się do skalanych grzechem sodomii, wzywał: „Wejrzyjcie w siebie, przeklęci, jakiej zaprzedaliście się obrzydliwej namiętności! (...). Postarajcie się jak najszybciej porzucić tę najbardziej plugawą i cuchnącą namiętność, znienawidzić ją, a jeśli ktokolwiek twierdzi, że jest to coś niewinnego, tego poddajcie wiecznej anatemie jako sprzeciwiającego się Ewangelii Chrystusa Zbawiciela i wypaczającego Jego naukę. Oczyśćcie się szczerym pokajaniem, gorącymi łzami, jałmużną i czystą modlitwą (...). Z całej duszy miejcie w nienawiści tę niegodziwość, abyście nie stali się synami przekleństwa i wiecznej zguby".

Dyskusje na temat statusu tak zwanych mniejszości seksualnych we współczesnym społeczeństwie wykazują tendencję do uznania homoseksualizmu nie za seksualną rozwiązłość, lecz tylko za jedną z „orientacji płciowych”, które mają równe prawo do funkcjonowania w sferze publicznej i zasługują na szacunek. Argumentuje się również, że pociąg homoseksualny wynika $\mathrm{z}$ indywidualnego naturalnego usposobienia. Kościół prawosławny wychodzi $\mathrm{z}$ niezmiennego przekonania, że ustanowionego przez Boga związku małżeńskiego między mężczyzną i kobietą nie można porównywać $\mathrm{z}$ wypaczonymi przejawami seksualności. Uważa on homoseksualizm za krzywdę wyrządzoną ludzkiej naturze przez grzech, która może zostać pokonana przez prowadzący do uzdrowienia i doskonałości osobistej wysiłek duchowy. Ideowe aspiracje homoseksualne, podobnie jak inne dręczące upadłego człowieka namiętności, są uzdrawiane przez Sakramenty, modlitwę, pokajanie, lekturę Pisma Świętego i dzieł Ojców Kościoła, a także chrześcijańskie relacje $\mathrm{z}$ wierzącymi ludźmi, którzy są gotowi okazać im duchowe wsparcie.

Odnosząc się do ludzi o skłonnościach homoseksualnych z duszpasterską odpowiedzialnością, Kościół jednocześnie zdecydowanie sprzeciwia się próbom zmierzającym do uznania grzesznego trendu za „normę”, a tym bardziej za powód do dumy i przykład do naśladowania. Dlatego Kościół potępia wszelką promocję homoseksualizmu. Nie odmawiając nikomu podstawowych praw do życia, poszanowania godności osobistej i aktywnego udziału w życiu społecznym, Kościół uważa jednak, że osoby, 
które promują homoseksualny styl życia, nie powinny być dopuszczane do nauczania, wychowania i innych form pracy z dziećmi i młodzieżą, a także do zajmowania kierowniczych stanowisk w wojsku i zakładach penitencjarnych.

Czasami aberracje ludzkiej seksualności przejawiają się $\mathrm{w}$ postaci bolesnego poczucia przynależności do płci przeciwnej, co w rezultacie prowadzi do podjęcia próby zmiany płci (transseksualizm). Dążenie do zmiany przynależności płciowej, którą człowiek został obdarzony przez Stwórcę, może mieć tylko i wyłącznie szkodliwe konsekwencje dla dalszego rozwoju ludzkiej osoby. „Zmiana płci” poprzez terapię hormonalną i operację chirurgiczną $\mathrm{w}$ wielu przypadkach nie prowadzi do rozwiązania problemów psychologicznych, lecz do ich nasilenia, przyczyniając się do głębokiego kryzysu wewnętrznego. Kościół nie może zaakceptować tego „buntu przeciw Stwórcy” i uznać sztuczną zmianę przynależności płciowej za realną. Jeśli „Zmiana płci” nastąpiła u człowieka, zanim zdecydował się on przyjąc chrzest, wówczas może on przystąpić do tego Sakramentu jak każdy grzesznik, jednakże Kościół udzieli mu chrztu jako osobie o płci, w której się urodził. Wyświęcenie takiej osoby do stanu duchownego oraz zawarcie przez nią kościelnego związku małżeńskiego nie jest dopuszczalne.

Konieczne jest, aby transseksualizm odróżnić od nieprawidłowej identyfikacji płci we wczesnym dzieciństwie w wyniku błędu medycznego związanego z patologią rozwoju cech płciowych. W rzeczonym przypadku korekta chirurgiczna nie ma charakteru zmiany płci.

\section{Rozdział XIII - Kościół i problemy ekologii}

1. Kościół prawosławny, świadomy swojej odpowiedzialności za los świata, jest głęboko zaniepokojony problemami spowodowanymi przez współczesną cywilizację. Ważne miejsce wśród nich zajmują problemy ekologii. Obecnie dokonuje się deformacja oblicza Ziemi na globalną skalę. Skażeniu uległy głębiny ziemi, gleba, woda, powietrze, fauna i flora. Otaczająca nas przyroda praktycznie w całości została wprzęgnięta w podtrzymanie życia człowieka, którego nie satysfakcjonuje już bogata różnorodność jej darów, lecz w nieograniczony sposób eksploatuje on całe jej ekosystemy. Aktywność ludzka, która osiągnęła zakres współmierny do procesów zachodzących w biosferze, stale wzrasta wskutek przyspieszonego tempa rozwoju nauki i technologii. Powszechne zanieczyszczenie środowiska odpadami przemysłowymi, niewłaściwe zastosowanie technologii rolniczych, niszczenie lasów i dewastacja gleby prowadzą do zahamowania aktywności biologicznej oraz nieustannej redukcji genetycznej różnorodności form życia. Nieodnawialne źródła surowców mineralnych są na wyczerpaniu, zmniejszają się zasoby wody czystej. Ponadto pojawia się mnóstwo szkodliwych substancji, spośród których wiele pozostaje poza naturalnym cyklem przemian zachodzących w przyrodzie i kumuluje się w biosferze. Równowaga ekologiczna została naruszona; człowiek zaś stoi przed faktem zaistnienia nieodwracalnych, szkodli- wych procesów w przyrodzie, w tym także zaburzenia jej naturalnych zdolności do regeneracji.

Wszystko to dokonuje się na tle bezprecedensowego i nieznajdującego uzasadnienia powszechnego wzrostu konsumpcji w krajach wysoko rozwiniętych, w których egzystencjalną normą stało się dążenie do bogactwa i luksusu. W takich okolicznościach powstają trudności w zakresie sprawiedliwej dystrybucji zasobów naturalnych, które stanowią dziedzictwo całej ludzkości. Konsekwencje kryzysu ekologicznego okazały się bolesne nie tylko dla przyrody, ale także człowieka, który jest jej integralną częścią. W rezultacie Ziemia znalazła się na progu globalnej katastrofy ekologicznej.

2. Relacje między człowiekiem i otaczającą go przyrodą zostały zaburzone już w czasach prehistorycznych. Przyczyną tego stanu rzeczy był grzeszny upadek człowieka i jego odejście od Boga. Grzech, który zrodził się w ludzkiej duszy, negatywnie wpłynął nie tylko na niego samego, ale także na cały otaczający go świat. „Stworzenie - pisał apostoł Paweł - zostało poddane marności nie $\mathrm{z}$ własnej woli, lecz przez Tego, który je poddał, w nadziei, że również ono będzie wyzwolone $\mathrm{z}$ niewoli rozkładu do wolności chwały dzieci Boga. Wiemy bowiem, że aż dotąd całe stworzenie wzdycha i rodzi się w bólach" (Rz 8, 20-22). Pierwszy występek człowieka odbił się w przyrodzie jak w lustrze. Po tym, jak nasienie grzechu dało owoc w ludzkim sercu, zrodziło, jak świadczy o tym Pismo Święte, „ciernie i osty” (Rdz 3, 18) na ziemi. Istniejąca przed upadkiem pełna organiczna jedność człowieka i otaczającego go świata stała się niemożliwa (Rdz 2, 19-20). W swoich relacjach z przyrodą, które przybrały charakter konsumpcyjny, ludzie w coraz większym stopniu kierowali się egoistycznymi pobudkami. Zaczęli zapominać, że jedynym Władcą Wszechrzeczy jest Bóg (Ps. 23, 1), do Którego należą ,niebiosa, ziemia i wszystko, co się na niej znajduje" (Pwt 10,14), podczas gdy człowiek, zgodnie ze słowami świętego Jana Chryzostoma, jest tylko „zarządcą", któremu zostało powierzone bogactwo ziemskiego świata. To bogactwo - „powietrze, słońce, wodę, ziemię, niebo, morze, światłość, gwiazdy", jak zauważa tenże święty, Bóg „podzielił równo pomiędzy wszystkich, jak między braci”. „Władza” nad przyrodą i „panowanie” nad ziemią (Rdz 1,28), do czego, zgodnie z planem Bożym, człowiek został powołany, nie oznacza, że wszystko jest dozwolone. Świadczy to jedynie o tym, że człowiek dzierży obraz niebiańskiego Władcy i jako taki powinien, jak stwierdza święty Grzegorz z Nyssy, okazywać swą królewską godność nie przez dominację i przemoc nad otaczającym go światem, lecz przez „uprawę” i „ochronę” (Rdz 2,15) wspaniałego królestwa przyrody, za które odpowiada przed Bogiem.

3. Kryzys ekologiczny obliguje nas do ponownego rozważenia naszych relacji z otaczającym światem. Obecnie koncepcja dominacji człowieka nad światem przyrody i konsumpcyjny stosunek do niej są coraz bardziej krytykowane. Świadomość, że współczesne społeczeństwo płaci zbyt wysoką cenę za osiągnięcia cywilizacji, wywołuje sprzeciw wobec gospodarczego egoizmu. Identyfikowane 
są działania, które przynoszą szkodę środowisku. Jednocześnie jest opracowywany system jego ochrony, weryfikowane są metody zarządzania oraz podejmowane są próby opracowania technologii oszczędzających zasoby naturalne i produkcji bezodpadowej, które jednocześnie mogłyby „zintegrować się” z naturalnym cyklem przyrody. Rozwija się także etyka ekologiczna. Ukierunkowana przez nią świadomość społeczna sprzeciwia się konsumpcyjnemu stylowi życia, domaga się zwiększenia moralnej i prawnej odpowiedzialności za szkody wyrządzone przyrodzie, postuluje wprowadzenie wychowania i edukacji ekologicznej, wzywa do podjęcia wspólnych działań na rzecz ochrony środowiska $w$ oparciu o szeroką współpracę międzynarodową.

4. Kościół prawosławny docenia wysiłki ukierunkowane na przezwyciężenie kryzysu ekologicznego i wzywa do aktywnej współpracy w ramach akcji społecznych, mających na celu ochronę stworzenia Bożego. Jednocześnie zauważa, że tego rodzaju wysiłki będą bardziej owocne, jeżeli fundamenty, na których zostaną zbudowane relacje człowieka z przyrodą, będą miały charakter nie tylko czysto humanistyczny, ale także chrześcijański. Jedną z głównych zasad stanowiska Kościoła w kwestiach ekologicznych jest zasada jedności i integralności świata stworzonego przez Boga. Prawosławie nie rozpatruje otaczającej nas przyrody w odizolowaniu, jako zamkniętej struktury. Swiaty roślin, zwierząt i ludzi są ze sobą wzajemnie powiązane. $Z$ perspektywy chrześcijańskiej przyroda nie jest magazynem zasobów przeznaczonych do egoistycznej i nieodpowiedzialnej eksploatacji, ale domem, gdzie człowiek nie jest gospodarzem, lecz zarządcą. Jest ona świątynią, w której człowiek nie jest kapłanem przyrody, lecz służy jedynemu Stwórcy. Pojmowanie przyrody jak świątyni znajduje oparcie w idei teocentryzmu: Bóg, Który „daje wszystkim życie i oddech, i wszystko" (Dz 17:25), jest Źródłem istnienia. Dlatego samo życie w swoich różnych przejawach jest święte, jest darem Boga, którego podeptanie jest prowokacyjnym wyzwaniem rzuconym nie tylko boskiemu stworzeniu, ale samemu Panu.

5. Problemy ekologiczne z natury mają charakter antropologiczny, ponieważ są generowane przez człowieka, a nie przez przyrodę. Dlatego odpowiedzi na wiele pytań związanych z kryzysem środowiska są zawarte w ludzkiej duszy, a nie w dziedzinie ekonomii, biologii, technologii czy polityki. $\mathrm{W}$ istocie przyroda ulega przeobrażeniom lub ginie nie sama z siebie, ale wskutek działań człowieka. Stan jego ducha odgrywa decydującą rolę, ponieważ pozostawia na środowisku swe piętno, zarówno jeśli chodzi o jego zewnętrzne oddziaływanie, jak i brak tego oddziaływania. Historia Kościoła zna mnóstwo przykładów, gdy miłość chrześcijańskich ascetów do przyrody, ich modlitwa za otaczający świat i współczucie okazywane wszelkiemu stworzeniu miały w najwyższym stopniu dobroczynny wpływ na istoty żywe.

Wzajemna zależność antropologii i ekologii z niezwykłą jasnością uwidacznia się w obecnych czasach, gdy świat doświadcza jednocześnie dwóch kryzysów: duchowego i ekologicznego. We współczesnym społeczeństwie czasami umyka świadomości człowieka fakt, że życie jest darem Boga, a niekiedy nawet sam sens istnienia, które czasem sprowadza się do fizycznej egzystencji. W przypadku takiego stosunku do życia otaczająca przyroda nie jest już postrzegana jak dom, a tym bardziej jak świątynia, stając się jedynie „miejscem zamieszkania”. Zdegenerowana duchowo osoba doprowadza do degeneracji także przyrodę, ponieważ przez swoje działanie nie jest w stanie przemieniać świata. Zaślepionej przez grzech ludzkości nie pomagają w tym nawet ogromne możliwości techniczne. Przy obojętności na sens, tajemnicę i cud życia nie przynoszą one rzeczywistych korzyści, a czasem nawet wyrządzają szkody. Dla człowieka, którego działania nie są zorientowane duchowo, potęga techniki z zasady jest źródłem utopijnych nadziei na osiągnięcie nieograniczonych możliwości ludzkiego rozumu i siłę sprawczą postępu.

Całkowite przezwyciężenie kryzysu ekologicznego w warunkach kryzysu duchowego jest nie do pomyślenia. Ta diagnoza wcale nie oznacza, że Kościół wzywa do ograniczenia działań na rzecz ochrony środowiska. Łączy on jednak nadzieję na pozytywną zmianę relacji między człowiekiem a przyrodą z dążeniem społeczeństwa do odnowy duchowej. Antropogeniczna osnowa problemów ekologicznych ukazuje, że zmiany, których dokonujemy w otaczającym nas środowisku, zachodzą w zgodzie z naszym światem wewnętrznym i dlatego transformacja przyrody powinna rozpocząć się od przemiany duchowej nas samych. Według świętego Maksyma Wyznawcy człowiek może zmienić w raj całą ziemię tylko wtedy, gdy raj nosi w samym sobie.

(Przektadu z języka rosyjskiego dokonat ks. Artur Aleksiejuk)

\section{Bibliografia}

Cerkov' i problemy ekologii. (2000). W: Osnovy social'noj koncepcii Russkoj Pravoslavnoj Cerkvi. [on-line] https://mospat.ru/ru/documents/social-concepts/xiii/, [29.06.2020].

Novik, V. (2000). Analiz 1-5 glav «Osnov social'noj koncepcii Russkoj Pravoslavnoj Cerkvi», Religiâ i pravo, 5, 67-75.

Obywatel poza Cerkwią. Z prof. Władsławem Arżanuchinem rozmawia Jan Strzałka. (2000). [on-line] http://www.tygodnik. com.pl/numer/274608/strzalka.html, [29.06.2020].
O dokumente. (2000). W: Osnovy social'noj koncepcii Russkoj Pravoslavnoj Cerkvi. [on-line] https://mospat.ru/ru/documents/social-concepts/about/, [29.06.2020].

Opredelenie «O vzaimootnošeniâh Cerkvi s gosudarstvom i svetskim obŝestvom na kanoničeskoj territorii Moskovskogo Patriarhata v nastoâsee vremiâ». (1994). Arhierejskij Sobor RPC, 29.11-2.12.1994. [on-line] http://www.patriarchia.ru/ $\mathrm{db} /$ text/530460.html, [29.06.2020]. 
Osnovysocial'noj koncepcii Russkoj Pravoslavnoj Cerkvi. (2000).

[on-line] https://mospat.ru/ru/documents/social-concepts/, [29.06.2020].

Problemy bioetiki. (2000). W: Osnovy social'noj koncepcii Rus- skoj Pravoslavnoj Cerkvi. [on-line] https://mospat.ru/ru/ documents/social-concepts/xii/, [29.06.2020].

Žurnaly zasedaniâ Svâsennogo Sinoda ot 19 iûlâ 2000. (2000). [on-line] http://www.patriarchia.ru/db/text/4904356.html, [29.06.2020].

Rozmiar artykułu: 1,5 arkusza wydawniczego 